\title{
Metode Spektrofotometri Secara Tidak Langsung untuk Penentuan Merkuri(II) berdasarkan Pembentukan Kompleks Biru Iodium-Amilum
}

\author{
Hermin Sulistyartia $^{a, c^{*}}$, Erwin Sulistyo ${ }^{b, c,}$, Sutrisno Sutrisno ${ }^{a, c}$, Zuri Rismiartia,c \\ ${ }^{a}$ Jurusan Kimia, Universitas Brawijaya \\ ${ }^{b}$ Jurusan Teknik Mesin, Universitas Brawijaya \\ "Research Center of "Low Cost \& Automated Method and Instrumentation Analysis" (LCAMIA), Jurusan \\ Kimia, Universitas Brawijaya, Jl. Veteran Malang 65145 \\ *Corresponding author \\ *E-mail:hermin@ub.ac.id
}

DOI: 10.20961/alchemy.15.1.15036.149-164

Received 08 October 2017, Accepted 27 February 2019, Published 01 March 2019

\begin{abstract}
ABSTRAK
Metode spektrofotometri secara tidak langsung telah dikembangkan untuk analisis merkuri(II) berdasarkan perbedaan absorbansi kompleks biru amilum-iodium antara larutan sampel yang mengandung ion merkuri(II) dan larutan blanko yang tidak mengandung ion merkuri(II) dalam sistem pereaksi yang berisi iodida, iodat dan amilum. Pada larutan blanko, semua ion iodida ( $\left.\mathrm{I}^{-}\right)$dalam sistem pereaksi dioksidasi oleh iodat menjadi iodium yang dengan adanya amilum membentuk kompleks biru iodium-amilum dan terdeteksi secara spektrofotometri pada $618 \mathrm{~nm}$. Namun, bila sampel mengandung ion merkuri(II), maka sebagian ion iodida akan terikat oleh ion merkuri(II) dan membentuk kompleks tetraiodomerkurat(II), sehingga hanya sisa iodida yang dioksidasi oleh ion iodat menjadi iodium dan membentuk warna biru dengan absorbansi yang lebih rendah dibandingkan absorbansi larutan blanko. Hasil penelitian menunjukkan bahwa perbedaan absorbansi sebanding dengan konsentrasi iodida yang terikat pada ion merkuri(II) sehingga sebanding pula dengan konsentrasi merkuri(II) dalam sampel. Metode yang dikembangkan dioptimasi terhadap beberapa parameter kimia, antara lain konsentrasi larutan iodida, iodat, amilum, dan $\mathrm{pH}$ larutan dan pada kondisi optimum memberikan kisaran linier $1-9 \mathrm{mg} \mathrm{L}^{-1}$ ion merkuri(II) dengan $\mathrm{R}^{2}$ 0,9983, dengan LOD 0,44 $\mathrm{mg} \mathrm{L}^{-1}$. Metode ini cukup selektif terhadap ion kobalt(II) dan timbal(II), namun ion tembaga(II) dan perak(I) mengganggu pengukuran. Metode ini telah divalidasi menggunakan metode adisi standar yang diaplikasikan ke dalam sampel limbah pertambangan emas dari Lombok dengan hasil yang memuaskan.
\end{abstract}

Kata Kunci : iodat, iodida, iodium-amilum, merkuri(II), spektofotometri

\begin{abstract}
Indirect Spectrophotometry for Mercury(II) Determination Based on The Formation of Blue Starch-Iodine Complex. Indirect spectrophotometric method for determining mercury(II) concentration has been successfully developed based on the difference of the absorbance of the blue starch-iodine complex in the absence and in the presence of mercury(II). In the absence of mercury(II), all iodide ions ( $\mathrm{I}^{-}$) in the reagent system are oxidized by iodate to iodine, which in the presence of starch formed a clear blue complex of starchiodine detected spectrophotometrically at $618 \mathrm{~nm}$. However, if mercury presents in the sample, some of the iodide ions are bound to mercury(II) ion forming tetraiodomercurate(II) complex, and thus, only the remaining of iodide is oxidized by iodate to iodine resulting in lower absorbance of the blue color. The results showed
\end{abstract}


that the delta absorbance was proportional to the concentration of iodide bound to mercury and thus proportional to mercury(II) concentration. To achieve the sensitivity, the method was optimized to the main chemical parameters, such as the concentration of iodide, iodine, iodate, starch, and $\mathrm{pH}$ solution. Selectivity of the method was also studied by investigating the effect of interfering ions of copper(II), cobalt (II), lead(II), and silver (I). Under these optimum conditions, the method showed linearity measurements from $1-9 \mathrm{mg} \mathrm{L}^{-1}$ mercury(II) with correlation $\left(\mathrm{R}^{2}\right)$ of 0.996 . The method was also successfully applied to determine mercury(II) from small-scale gold mining tailing waste from West Lombok, Indonesia and is prospective for analysis of mercury(II) in mining waste.

Keywords: iodate, iodide, mercury(II), spectrophotometry, starch-iodine

\section{PENDAHULUAN}

Menurut WHO merkuri merupakan salah satu dari sepuluh bahan kimia berbahaya yang menjadi prioritas perhatian masyarakat dunia. Hal ini dikarenakan, dalam jumlah kecil, merkuri dapat menyebabkan masalah kesehatan akut seperti keguguran, kerusakan otak, tumor, ginjal, masalah kulit dan mata dan bahkan kematian (WHO, 2003; US-EPA, 1997). Merkuri berada di lingkungan melalui udara, air, atau organisme melalui rantai makanan dan bisa berubah menjadi senyawa metil merkuri yang lebih beracun. Mengingat sifat merkuri yang mudah menguap dan masuk ke dalam sistem rantai makanan, maka polusi merkuri telah lama menjadi perhatian global (Renneberg et al., 2001).

Aktifitas manusia yang menyebabkan polusi merkuri antara lain pertambangan batubara, pertambangan emas skala kecil, produksi baja, baterai, pabrik kimia, dan farmasi (Burgot, 2012). Ibarat Amerika yang mengalami gold rush disekitar tahun 1848-an, saat ini Indonesia sedang mengalami demam emas atau gold fever (Jeffrey et al., 1998). Hal ini terlihat dari banyaknya penambangan emas rakyat yang dikenal sebagai GSM (Gold Small scale Mining) yang telah banyak ditemukan di berbagai daerah di Indonesia, diantaranya Jambi, Jawa Barat, Kalimantan Tengah, Kalimantan Barat, Nusa Tenggara Barat, Sulawesi Utara, serta Palu-Sulawesi Tengah Penambangan emas rakyat ini umumnya menggunakan metode amalgamasi yang menggunakan merkuri yang sangat beracun sehingga sangat berbahaya bagi manusia maupun lingkungan (Kaiho, 2014).

Metode penentuan merkuri(II) popular adalah menggunakan CV-AAS (cold vapor atomic absorption spectrophotometry) dengan memanfaatkan sifat logam merkuri yang mudah menguap. Teknik ini melibatkan reduksi ion merkuri(II) menjadi logam merkuri menggunakan reduktor natrium tetrahidroborat(III) atau tin(II)klorida (Grenberg et al., 1992). Metode tersebut dapat mendeteksi merkuri hingga skala ultra trace, akurasi dan presisi yang tinggi tetapi memerlukan keahlian analisis dan instrumentasi yang cukup rumit (Leal et al., 2006). Oleh sebab itu, metode spektrofotometri UV-Vis masih menjadi teknik 
analisis lebih disukai, khususnya di negara berkembang karena kemudahan dalam analisis dan teknik operasional (Hageman et al., 2007).

Metode penentuan merkuri secara spektrofotometri UV-Vis telah banyak dikembangkan dengan menggunakan reagen pengompleks seperti dithizon (Grenberg et al., 1992), 6-hydroxy-3-(2-oxoindolin-3-ylideneamino)-2-thioxo-2H-1,3-thiazin-4(3H); 2mercapto-benzothiazole (MBT) (Hamza et al., 2010), diacetyl monoxime isonicotinoyl hydrazone (DMIH) (Reddy, 2011), iodide-rhodamine (Loo et al., 2012). anthrone phenyl hydrazone (APH) (Veerana et al., 2011). Metode tersebut masih melibatkan ekstraksi, sintesis, dan kondensasi dalam preparasi analisis merkuri(II) maupun pereaksinya. Oleh karena itu prosedur analisis yang mudah, sederhana dan tanpa perlakukan ekstraksi terlebih dahulu masih sangat diperlukan untuk analisis merkuri(II) (Svehla,1979).

Muralidhara (1998) melaporkan bahwa potassium iodide merupakan pereaksi selektif untuk pereaksi pelindung (masking agent) ion $\mathrm{Hg}(\mathrm{II})$ melalui pembentukan kompleks stabil dalam larutan sebagai tetraiodomerkurat(II), $\left[\mathrm{HgI}_{4}\right]^{2-}$ (Muralidhara, 1998). Sulistyarti (2015) melaporkan bahwa iodida teroksidasi oleh iodat membentuk iodium yang dengan adanya amilum membentuk larutan kompleks biru jernih yang dapat dideteksi menggunakan spektrofotometer pada $\lambda 618 \mathrm{~nm}$. Oleh karena itu, penelitian ini bertujuan untuk mengembangkan metode analisis merkuri(II) secara spektrofotometri secara tidak langsung (indirect spectrophotometry) berdasarkan pembentukan kompleks biru amilum-iodium menggunakan system pereaksi iodida-iodat. Bila dalam sistem pereaksi iodida-iodat tidak ada ion $\mathrm{Hg}(\mathrm{II})$, semua ion iodida $\left(\mathrm{I}^{-}\right)$dioksidasi oleh iodat menjadi iodium, sehingga membentuk kompleks biru amilum-iodium jernih dan terdeteksi secara spektrofotometri pada $618 \mathrm{~nm}$. Jika merkuri(II) berada dalam sistem pereaksi iodida-iodat, maka ion iodida akan bereaksi dengan ion merkuri(II) dan membentuk kompleks tetraiodomerkurat(II). Hanya ion iodida yang tersisa akan dioksidasi oleh iodat menjadi iodium yang menghasilkan warna biru dengan absorbansi yang lebih rendah (Sulistyarti et al., 2015).

Hasil penelitian pendahuluan menunjukkan bahwa perbedaan absorbansi sebanding dengan konsentrasi iodida yang terikat pada merkuri; sehingga sebanding pula dengan konsentrasi merkuri(II). Untuk mendapatkan sensitifitas metode yang memadai, kondisi kimiawi pereaksi yang berkontribusi terhadap proses pengukuran dioptimasi. Parameter kimiawi yang dioptimasi antara lain meliputi konsentrasi larutan iodida, iodat, amilum, dan $\mathrm{pH}$. Selektifitas metode ini juga diteliti dengan mempelajari pengaruh ion penganggu seperti ion tembaga(II), kobalt(II), timbal(II), dan perak(I) (Sulistyarti et al., 2015). Metode ini 
divalidasi menggunakan metode adisi standar yang diaplikasikan ke dalam sampel limbah pertambangan emas skala kecil dari Lombok Barat, Indonesia.

\section{METODE PENELITIAN}

Semua larutan dipersiapkan menggunakan akuadem. Larutan induk ion merkuri(II), iodida, iodat, tembaga(II), kobalt(II), timbal(II), perak(I), masing-masing disiapkan dari $\mathrm{HgCl}_{2}$ (Merck), $\mathrm{KI}$ (Merck), $\mathrm{KIO}_{3}$ (Merck), $\mathrm{Cu}\left(\mathrm{NO}_{3}\right)_{2}$ (Merck), $\mathrm{Co}\left(\mathrm{NO}_{3}\right)_{2}$ (Merck), $\mathrm{Pb}\left(\mathrm{NO}_{3}\right)_{2}$ (Merck), $\mathrm{AgNO}_{3}$ (Merck) dengan asam $\mathrm{HNO}_{3}$ (Merck). Larutan amilum 1\% disiapkan secara langsung dengan melarutkan $1 \mathrm{~g}$ amilum (Sigma) dalam akuadem panas. Semua bahan kimia merupakan analytical reagent grade. Larutan kerja disiapkan dengan pengenceran secara kuantitatif dari larutan induk masing-masing larutan. Peralatan yang digunakan dalam penelitian ini adalah spektrofotometer UV-Vis SHIMADZU 1601.

\section{Optimasi metode}

Optimalisasi dilakukan dengan cara merubah hanya satu parameter sedangkan parameter lain dalam keadaan sama/konstan. Pertama, optimasi metode dilakukan untuk mencari konsentrasi iodida yang optimum. Percobaan ini dilakukan dengan menyiapkan larutan standar merkuri(II) 1 - $10 \mathrm{mgL}^{-1}$ dengan memipet larutan stock merkuri(II) $100 \mathrm{mg} / \mathrm{L}$ dengan volume yang sesuai dan dimasukkan ke dalam labu ukur $10 \mathrm{~mL}$. Selanjutnya larutan tersebut ditambah larutan pereaksi, yaitu larutan $0,3 \mathrm{~mL}$ iodida $500 \mathrm{mg} \mathrm{L}^{-1}, 1,0 \mathrm{~mL}$ asam nitrat $1 \mathrm{M}, 0,5 \mathrm{~mL}$ larutan amilum $1 \%$, dan $0,35 \mathrm{~mL}$ iodidat $50 \mathrm{mg} \mathrm{L}^{-1}$ dan ditambahkan akuadem hingga tanda batas. Absorbansi larutan kompleks biru yang terbentuk dari iodiumamilum diukur menggunakan spektrofotometer UV-Vis pada panjang gelombang $(\lambda) 618$ $\mathrm{nm}$. Prosedur yang sama digunakan untuk konsentrasi iodida lainnya dengan memvariasikan volume $500 \mathrm{mg} \mathrm{L}^{-1}$ iodida antara 0,3 sampai $0,6 \mathrm{~mL}$ yang setara dengan konsentrasi iodida $15-30 \mathrm{mg} \mathrm{L}^{-1}$.

Optimasi konsentrasi iodat juga dilakukan dengan prosedur yang sama dengan memvariasikan volume larutan iodat $50 \mathrm{mg} \mathrm{L}^{-1}$ dari 0,3 sampai 0,6 $\mathrm{mL}$ (yang setara dengan konsentrasi iodat $1,5-3 \mathrm{mg} \mathrm{L}^{-1}$ ) dengan menggunakan konsentrasi optimum iodida. Optimasi $\mathrm{pH}$ juga dilakukan dengan prosedur yang sama namun $\mathrm{pH}$ divariasi dari $1-5$ dengan menggunakan larutan $\mathrm{HNO}_{3}$ dengan konsentrasi optimum iodida dan iodat. Optimasi larutan amilum sebagai indikator dalam kompleks iodium juga dilakukan dengan memvariasikan volume larutan amilum $1 \%$ dari $0,1-1 \mathrm{~mL}(0,01-0,1 \%)$ dengan konsentrasi optimum iodida, iodat dan $\mathrm{pH}$ larutan. 


\section{Linieritas}

Linieritas pengukuran dilakukan menggunakan kondisi optimum dari semua parameter, yaitu konsentrasi iodida $15 \mathrm{mg} \mathrm{L}^{-1}$, konsentrasi iodat $3 \mathrm{mg} \mathrm{L}^{-1}, \mathrm{pH} 1\left(\mathrm{HNO}_{3}\right)$, dan konsentrasi amilum 0,05\%. Kondisi optimum tersebut diaplikasikan pada pengukuran absorbansi larutan merkuri(II) dengan konsentrasi dari $1-10 \mathrm{mgL}^{-1}$ dan dibuat kurva kalibrasi antara konsentrasi merkuri(II) vs absorbansi.

\section{Pengaruh Ion Asing}

Pengaruh ion pengganggu seperti tembaga(II), kobalt(II), timbal(II), perak(I) dipelajari untuk mengetahui selektivitas metode. Percobaan ini dilakukan dengan cara memipet larutan $\mathrm{Hg}^{2+} 100$ ppm sebanyak $0,1 \mathrm{~mL}$ ke dalam 4 labu ukur $10 \mathrm{~mL}$ yang berbeda. Kemudian, masing-masing ditambahkan ion asing $\mathrm{Cu}$ (II) dengan konsentrasi 0; 1, 5; 10 ppm dan reagen sesuai hasil optimasi, serta ditambah akuabidest hingga tanda batas dan dikocok hingga homogen. Larutan ini kemudian dibaca absorbansinya menggunakan spektrofotometer pada $\lambda 618 \mathrm{~nm}$. Perlakuan yang sama dilakukan untuk ion asing $\mathrm{Co}^{2+}, \mathrm{Pb}^{2+}$, dan $\mathrm{Ag}^{+}$.

\section{Validasi metode}

Metode yang dikembangkan diaplikasikan ke dalam penentuan merkuri(II) dalam sampel sampel limbah pertambangan emas skala kecil dari Lombok Barat, Indonesia dengan menggunakan metode adisi standar. Percobaan dilakukan dengan menyiapkan empat labu takar $10 \mathrm{~mL}$ yang masing-masing diisi $0,1 \mathrm{~mL}$ limbah tersebut. Selanjutnya, larutan standar merkuri(II) dengan konsentrasi 0,1 , 2, dan $3 \mathrm{mg} \mathrm{L}^{-1}$ ditambahkan ke dalam masing-masing labu takar $10 \mathrm{~mL}$ tersebut, kemudian diberi pereaksi dengan konsentrasi kondisi optimum yang telah diperoleh, ditambah akuabidest hingga tanda batas, dan dikocok hingga homogen. Larutan biru yang terbentuk dibaca absorbansinya menggunakan spektrofotometer pada $\lambda$ $618 \mathrm{~nm}$ dan dihitung \% Recovery-nya dengan membandingkannya dengan absorbansi sampel tanpa penambahan merkuri(II).

\section{PEMBAHASAN}

Metode spektrofotometri baru untuk analisis merkuri(II) yang dikembangkan didasarkan perbedaan absorbansi kompleks biru amilum-iodium antara larutan sampel yang mengandung ion merkuri(II) dan larutan blanko yang tidak mengandung ion merkuri(II) dalam sistem pereaksi yang berisi iodida, iodat dan amilum.

Pada larutan blanko, semua ion iodida $\left(\mathrm{I}^{-}\right)$dalam sistem pereaksi dioksidasi oleh iodat menjadi iodium (Reaksi 1) yang dengan adanya amilum membentuk kompleks biru amilumiodium (Reaksi 2) dan terdeteksi secara spektrofotometri pada $618 \mathrm{~nm}$ dengan absorbansi 
$\mathrm{A}_{1}$. Sampel mengandung ion merkuri(II), maka sebagian ion iodida akan terikat oleh ion merkuri(II) dan membentuk kompleks tetraiodomerkurat(II) seperti pada Reaksi 3. Sisa iodida yang dioksidasi oleh iodat menjadi iodium (Reaksi 4) yang menghasilkan kompleks biru amilum-iodium (Reaksi 5) dengan absorbansi yang lebih rendah $\left(\mathrm{A}_{2}\right)$ dibandingkan dengan absorbansi larutan blanko $\left(\mathrm{A}_{1}\right)$. Makin besar konsentrasi merkuri(II) makin banyak iodida yang terikat sebagai kompleks tetraiodomerkurat(II), sehingga semakin kecil jumlah iodida yang tersisa dan akibatnya semakin kecil nilai absorbansi dan perbedaan (delta) absorbansi blanko terhadap sampel menjadi semakin besar. Jadi delta absorbansi merupakan absorbansi yang setara dengan konsentrasi iodida yang terikat merkuri(II) dan juga setara dengan konsentrasi merkuri(II). Delta absorbansi sebanding dengan konsentrasi merkuri(II), makin besar konsentrasi merkuri dalam sampel, makin besar pula delta absorbansinya.

$$
\begin{array}{ll}
\text { Blanko: } & 5 \mathrm{I}^{-}+\mathrm{IO}_{3}{ }^{-}+6 \mathrm{H}^{+} \rightleftharpoons 3 \mathrm{I}_{2}+3 \mathrm{H}_{2} \mathrm{O} \\
& \left.\mathrm{I}_{2}+\text { Amilum } \rightarrow \mathrm{I}_{2} \text {-Amilum (biru, } \lambda 618 \mathrm{~nm}\right): \quad \mathrm{A}_{1} \\
\text { Sampel: } \quad & \mathrm{Hg}^{2+}+\mathrm{I}_{\text {(berlebih) }}^{-} \rightleftharpoons\left[\mathrm{HgI}_{4}\right]^{2-}+\mathrm{I}_{\text {(sisa) }}^{-} \\
& 5 \mathrm{I}^{-} \text {(sisa) }+\mathrm{IO}_{3}+6 \mathrm{H}^{+} \rightleftharpoons 3 \mathrm{I}_{2 \text { (sisa) }}+3 \mathrm{H}_{2} \\
& \mathrm{I}_{2 \text { (sisa) }}+\text { Amilum } \rightarrow \mathrm{I}_{2}-\text { Amilum }_{\text {(sisa) }}(\text { biru, } \lambda 618 \mathrm{~nm}): \quad \mathrm{A}_{2}
\end{array}
$$

$\Delta \mathrm{A}=\mathrm{A} 1-\mathrm{A} 2 \sim$ konsentrasi iodida terikat $\mathrm{Hg}(\mathrm{II}) \sim$ konsentrasi $\mathrm{Hg}(\mathrm{II})$ sampel

\section{Optimasi Iodida}

Optimasi iodida dilakukan untuk menentukan konsentrasi optimum pereaksi iodida yang menghasilkan sensitifitas metode paling tinggi berdasarkan perbedaan absorbansi terhadap perbedaan konsentrasi. Optimasi dilakukan dengan cara memvariasi larutan I- 500 mg $\mathrm{L}^{-1}$ dengan volume $0,3-0,6 \mathrm{~mL}$ dan diterapkan pada satu seri larutan merkuri(II) $1-10$ mg L ${ }^{-1}$. Hasil penelitian menunjukkan bahwa makin besar konsentrasi iodida, maka makin besar iodida yang tersisa yang teroksidasi oleh iodat menjadi iodium, sehingga dengan adanya amilum maka makin banyak kompleks biru iodium-amilum yang terbentuk ditandai dengan meningkatnya intensitas warna biru dan makin naiknya absorbansi dari penambahan 0,3 - 0,6 $\mathrm{mL}$ iodida $500 \mathrm{mg} \mathrm{L}^{-1}$ pada larutan merkuri(II) dengan semua konsentrasi (Gambar 1). Konsentrasi iodida berbanding lurus terhadap absorbansi kompleks $I_{2}$-amilum yang semakin meningkat, dan memberikan absorbansi tertinggi pada penambahan $0,6 \mathrm{~mL}$ iodida $500 \mathrm{mg} \mathrm{L}^{-1}$. Semakin besar penambahan iodida meningkatkan absorbansi larutan, namun, bila diterapkan untuk pengukuran merkuri(II) terlihat bahwa makin besar penambahan iodida, semakin tidak bisa membedakan konsentrasi merkuri (perbedaan absorbansi semakin kecil atau kurang sensitif). 
Oleh karena itu, penambahan $0,3 \mathrm{~mL}$ iodida $500 \mathrm{mg} \mathrm{L}^{-1}$ atau konsentrasi iodida $15 \mathrm{mg}$ $\mathrm{L}^{-1}$ yang menunjukkan sensitivitas yang paling tinggi dengan memberikan perbedaan absorbansi yang paling nyata untuk konsentrasi merkuri $1-10 \mathrm{mg} \mathrm{L}^{-1}$ dipilih sebagai kondisi optimum untuk pengukuran merkuri(II).

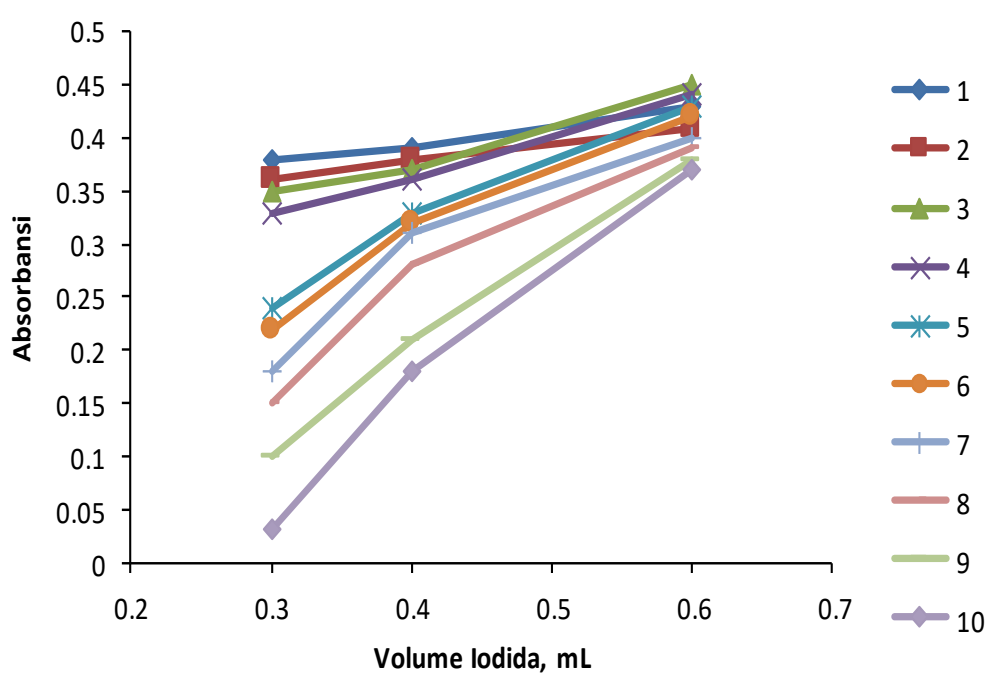

Gambar 1. Pengaruh volume iodida terhadap absorbansi pengukuran (Kondisi: 0,3 - 0,6

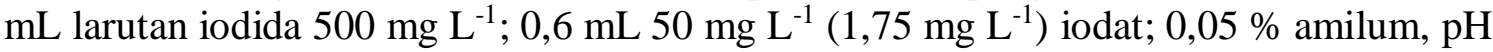
1, dan larutan merkuri $\left.1-10 \mathrm{mg} \mathrm{L}^{-1}\right)$.

\section{Optimasi Iodat}

Berdasarkan reaksi pada Gambar 2, terlihat bahwa ion iodat $\left(\mathrm{IO}_{3}^{-}\right)$berfungsi sebagai oksidator untuk mengoksidasi $\mathrm{I}^{-}$menjadi iodium $\left(\mathrm{I}_{2}\right)$ sehingga membentuk kompleks biru $\mathrm{I}_{2}$ amilum dengan penambahan indikator amilum. Penambahan oksidator $\mathrm{IO}_{3}{ }^{-}$berpengaruh terhadap kesempurnaan oksidasi iodida menjadi iodium dan pembentukan senyawa kompleks biru $\mathrm{I}_{2}$-amilum. Reaksi 1 dan 4 menunjukkan bahwa semakin banyak jumlah iodat kesetimbangan agar bergeser ke arah pembentukan produk $\mathrm{I}_{2}$ sesuai azas Le chatelier dengan cara mengoksidasi iodida bebas, demikian seterusnya sehingga semua iodida bebas dalam larutan sudah teroksidasi dengan sempurna menjadi iodium dan membentuk kompleks biru iodium-amilum (Reaksi 2 dan 5) dengan intensitas warna yang maksimum.

Hasil percobaan pengaruh konsentrasi iodat terhadap absorbansi kompleks $\mathrm{I}_{2}$-amilum disajikan pada Gambar 2 yang menunjukkan bahwa makin banyak konsentrasi iodat meningkatkan absorbansi kompleks $\mathrm{I}_{2}$-amilum untuk konsentrasi merkuri(II) yang rendah, yaitu 1 - $4 \mathrm{mg} \mathrm{L}^{-1}$. Hal ini dikarenakan pada konsentrasi merkuri rendah, maka iodida yang tersisa masih banyak, sehingga kenaikan jumlah iodat akan meningkatkan jumlah iodium yang terbentuk. Pada konsentrasi merkuri(II) yang lebih besar, $5 \mathrm{mg} \mathrm{L}^{-1}$, dimana jumlah iodida yang tersisa lebih kecil, maka peningkatan jumlah iodat tidak berpengaruh terhadap 
absorbansi, yang menunjukkan bahwa semua iodida pada penambahan iodat $3 \mathrm{~mL}$ telah teroksidasi menjadi iodium, dan penambahan iodat berikutnya tidak menambahkan jumlah iodium yang terbentuk, sehingga absorbansi yang diamati konstan. Pada konsentrasi merkuri(II) yang lebih besar, 6 - $10 \mathrm{mg} \mathrm{L}^{-1}$, dimana sisa iodida semakin kecil fenomena lain teramati, dimana penambahan iodat dari $3-4 \mathrm{~mL}$ meningkatkan absorbansi, namun pada penambahan iodat berikutnya, $5-6 \mathrm{~mL}$, dimana tidak ada lagi iodida yang tersisa penambahan iodat justru menurunkan absorbansi, bahkan untuk merkuri $10 \mathrm{mg} \mathrm{L}^{-1}$ penurunan absorbansi telah terjadi pada penambahan iodat $3 \mathrm{~mL}$. Hal ini dimungkinkan terjadinya reaksi lebih lanjut dari iodat yang berlebihan dengan iodium yang terbentuk sesuai Reaksi (6).

$$
\mathrm{IO}_{3}^{-}+2 \mathrm{I}_{2}+6 \mathrm{H}^{+} \rightleftharpoons 5 \mathrm{I}^{+}+3 \mathrm{H}_{2} \mathrm{O}
$$

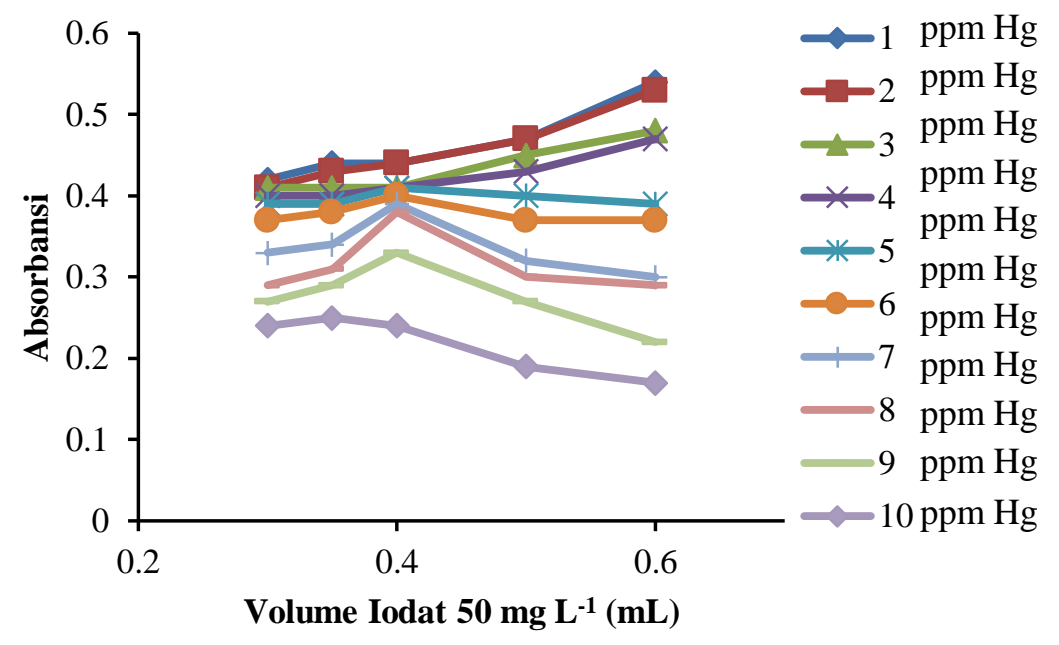

Gambar 2. Pengaruh volume iodat terhadap absorbansi pengukuran (Kondisi: $0,3 \mathrm{~mL}$ iodida $500 \mathrm{mg} \mathrm{L}^{-1} ; 0,3-0,6 \mathrm{~mL}$ iodat $50 \mathrm{mg} \mathrm{L}^{-1} ; 0,05 \%$ amilum; $\mathrm{pH} \mathrm{1,} \mathrm{larutan} \mathrm{merkuri} 1$ $\left.-10 \mathrm{mg} \mathrm{L}^{-1}\right)$.

Berdasarkan data pada Gambar 2 menunjukkan bahwa penambahan volume iodat 50 $\mathrm{mg} \mathrm{L}^{-1}$ sebesar $0,6 \mathrm{~mL}\left(3 \mathrm{mg} \mathrm{L}^{-1}\right)$ memberikan perbedaan absorbansi yang paling nyata untuk konsentrasi merkuri yang berbeda dari $1-10 \mathrm{mg} \mathrm{L}^{-1}$ yang sangat diperlukan untuk pengukuran, yaitu memberikan sensitivitas yang nyata. Kondisi tersebut juga memberikan gradasi penurunan warna biru kompleks $\mathrm{I}_{2}$-amilum paling jelas pada sampel yang mengandung $\mathrm{Hg}$ (II) 1 - $10 \mathrm{mg} \mathrm{L}^{-1}$. Oleh karena itu, konsentrasi $\mathrm{IO}_{3}{ }^{-}$sebesar $3 \mathrm{mg} \mathrm{L}{ }^{-1}$ dipilih sebagai konsentrasi iodat optimum yang digunakan untuk percobaan selanjutnya.

\section{Optimasi pH}

Derajat keasaman larutan merupakan hal yang sangat penting untuk menjamin terjadinya reaksi redoks sistem iodida-iodat. Pengujian pengaruh $\mathrm{pH}$ terhadap metode yang dikembangkan dimulai dari $\mathrm{pH} 1$, yaitu $\mathrm{pH}$ yang umum digunakan untuk reaksi redoks 
sistem iodat-iodida dengan hasil pengujian disajikan pada Gambar 3 yang menunjukkan perubahan $\mathrm{pH}$ secara signifikan mempengaruhi reaksi pembentukan kompleks amilumiodium, karena reaksi oksidasi iodida oleh iodat memerlukan kondisi asam seperti tertulis pada Reaksi 1 dan 4. Semakin kecil pH atau semakin asam larutan, berarti semakin banyak ion $\mathrm{H}^{+}$yang tersedia dalam larutan yang diperlukan untuk terjadinya reaksi redoks tersebut. Oleh karena itu, makin meningkatnya $\mathrm{pH}$ larutan, berarti semakin kecil ion $\mathrm{H}^{+}$yang tersedia dalam larutan dan menurunkan kesempurnaan reaksi redoks yang terjadi sehingga iodium yang terbentuk semakin sedikit dan mengakibatkan penurunan nilai absorbansi kompleks biru iodium-amilum.

Iodium dalam suasana basa akan terhidrolisis dan terdisproporsionasi menjadi asam hipoiodit dan iodida (Reaksi 7) dan pada pH 14 iodium menjadi ion iodit dan iodida (Reaksi 8). Sehingga $\mathrm{pH}$ makin besar iodium makin kurang stabil dan warna kompleks biru $\mathrm{I}_{2}$ amilum menjadi semakin pudar (Burgot, 2012; Kaiho, 2014). Disamping itu, larutan $\mathrm{Hg}$ (II) predominan spesies $\mathrm{Hg}^{2+}$, hanya pada $\mathrm{pH}$ yang sangat rendah $(\mathrm{pH}<3)$, sedangkan pada kisaran $\mathrm{pH} 3$ - 5 mulai terhidrolisis membentuk spesies $\mathrm{Hg}(\mathrm{OH})^{+}$, dan pada $\mathrm{pH}>6$ spesies $\mathrm{Hg}(\mathrm{II})$ semakin menurun dan hidroksinyanya, $\mathrm{Hg}(\mathrm{OH})_{2}$.

$$
\begin{aligned}
& \mathrm{I}_{2}+2 \mathrm{H}_{2} \mathrm{O} \rightleftharpoons \mathrm{HIO}+\mathrm{I}^{-}+\mathrm{H}^{+} \\
& \mathrm{I}_{2}+2 \mathrm{OH}^{-} \rightleftharpoons \mathrm{IO}^{-}+\mathrm{I}^{-}+\mathrm{H}_{2} \mathrm{O}
\end{aligned}
$$

Dari data Gambar 3 dapat diketahui bahwa pH 1 memberikan absorbansi tertinggi dan dipilih sebagai $\mathrm{pH}$ optimum yang digunakan untuk percobaan selanjutnya.

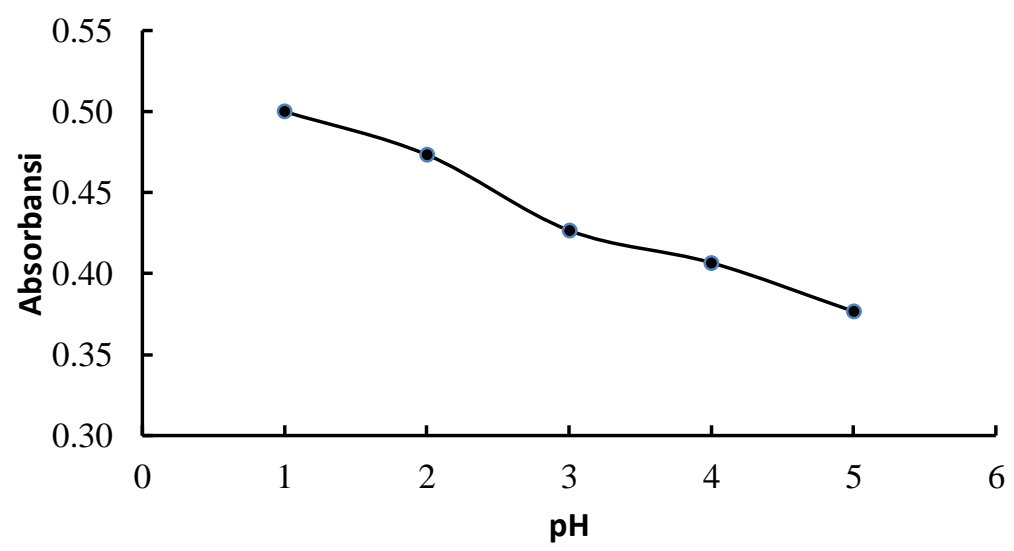

Gambar 3. Pengaruh $\mathrm{pH}$ terhadap absorbansi pengukuran $\left(\mathrm{I}_{2}\right.$-Amilum) (Kondisi: konsentrasi larutan merkuri(II) $4 \mathrm{mg} \mathrm{L}^{-1} ; 3 \mathrm{~mL} 500 \mathrm{mg} \mathrm{L}^{-1}$ iodida; $6 \mathrm{~mL} 50 \mathrm{mg} \mathrm{L}^{-1}$ iodat, $0.05 \%$ larutan amilum, dan $\mathrm{pH} 1-5)$.

\section{Optimasi konsentrasi amilum}

Amilum merupakan indikator spesifik untuk analisis iodium dengan memberikan warna biru dalam larutan. Hal tersebut terjadi karena adanya ikatan antara amilosa dan iodium yang membentuk komplek amilum-iodium. Gambar 4 menunjukkan pengaruh 
konsentrasi amilum $0,01-0,1 \%$ (melalui variasi penambahan volume $(0,1-1 \mathrm{~mL}$ ) amilum $1 \%$ ) terhadap absorbansi kompleks amilum-iodium. Seperti penambahan konsentrasi iodida dan iodat, peningkatan volume amilum ternyata juga meningkatkan nilai absorbansi. Hal tersebut menunjukkan bahwa semakin banyak amilum yang ditambahkan ke dalam sistem menyebabkan kompleks amilum-iodium semakin banyak yang mengakibatkan intensitas warna biru semakin tinggi atau semakin pekat. Hal ini sesuasi dengan konsep kesetimbangan dimana penambahan konsentrasi reagen (amilum) akan menggeser kesetimbangan ke arah produk (kompleks iodium-amilum).

Penambahan volume amilum $1 \mathrm{~mL}$ memberikan intensitas warna biru paling tinggi (ditunjukkan dengan absorbansi yang paling tinggi), namun penambahan $0,5 \mathrm{~mL}$ amilum 1 $\%$ memberikan perbedaan penurunan intensitas warna yang nyata untuk konsentrasi $\mathrm{Hg}$ (II) 1 - $10 \mathrm{mg} \mathrm{L}^{-1}$ dibandingkan dengan penambahan volume amilum yang lain, oleh karena itu, penambahan $0,5 \mathrm{~mL} 1 \%$ yang setara dengan $0,05 \%$ amilum dipilih sebagai kondisi konsentrasi amilum optimum.

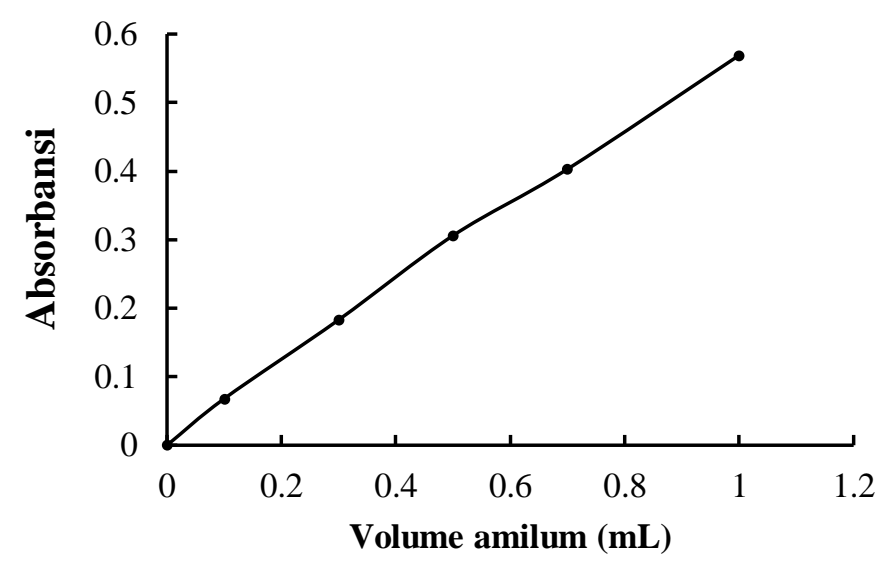

Gambar 4. Pengaruh konsentrasi amilum terhadap absorbansi pengukuran $\left(\mathrm{I}_{2}\right.$-Amilum) (Kondisi: Larutan $4 \mathrm{mg} \mathrm{L}^{-1}$ merkuri(II), $15 \mathrm{mg} \mathrm{L}^{-1}$ iodida, $3 \mathrm{mg} \mathrm{L}^{-1}$ iodat, $\mathrm{pH}$ 1).

\section{Penentuan Linieritas}

Linieritas pengukuran ditentukan menggunakan kondisi optimum dari semua parameter. Kondisi optimum dari percobaan yang telah dilakukan meliputi $15 \mathrm{mg} \mathrm{L}^{-1}$ iodida, $3 \mathrm{mg} \mathrm{L}{ }^{-1}$ iodat, $0.05 \%$ larutan amilum, and $\mathrm{pH} 1 \mathrm{HNO}_{3}$. Kondisi tersebut juga digunakan untuk penentuan kinerja metode yang dikembangkan yaitu selektifitas dan validitas. Penentuan linieritas bertujuan untuk mengetahui kisaran/rentang konsentrasi merkuri(II) yang dapat dianalisis menggunakan metode yang diusulkan. Merujuk dasar reaksi pengukuran (Reaksi 1-5) dan Persamaan 1, keberadaan ion merkuri dalam larutan akan menurunkan absorbansi larutan blanko dan semakin besar konsentrasi merkuri(II) 
penurunan absorbansi larutan semakin besar pula. Absorbansi yang terukur (teramati) tidak langsung di plot sebagai absorbansi, karena yang setara dengan konsentrasi merkuri(II) secara stoikhiometri adalah delta absorbansinya. Delta absorbansi ini setara dengan absorbansi ion merkuri(II) yang ada di dalam sampel, dan metode ini mengikuti hukum Lambert-Beer, $\mathrm{A}=$ abc atau $\mathrm{A}=\mathrm{kc}$, dimana makin besar konsentrasi (c) makin besar pula absorbansinya (A).

Kurva kalibrasi yang disajikan pada Gambar 5 menunjukkan hubungan yang linier antara konsentrasi merkuri(II) dan delta absorbansi, dimana absorbansi pada sumbu-y merupakan delta absorbansi antara larutan blanko dan larutan merkuri. Gambar 5 menunjukkan bahwa metode yang dikembangkan memberikan linieritas pengukuran merkuri(II) dari konsentrasi $1-9 \mathrm{mg} \mathrm{L}^{-1}$, dengan persamaan linier: $\mathrm{y}=0,1 \mathrm{x}-0,0399$ dan koefisien determinasi, $\mathrm{R}^{2}$, yang mendekati 1, yaitu 0.998. Koefisien korelasi (r) yang merupakan akar kuadrat dari koefisien determinasi dengan demikian juga mendekati 1, yaitu 0,999 sehingga menunjukkan hubungan linier positip yang kuat $(99,9 \%)$ antara konsentrasi merkuri(II) dan absorbansi. Metode penentuan limit deteksi menggunakan 3SD. Limit deteksi dari metode ini sebesar $0,44 \mathrm{mg} \mathrm{L}^{-1} \mathrm{Hg}(\mathrm{II})$, dengan standar deviasi relatif kurang dari $3 \%$, sehingga metode ini berpotensi sebagai metode alternatif untuk pengukuran konsentrasi $\mathrm{Hg}$ (II) antara $1-9 \mathrm{mg} \mathrm{L}^{-1}$. Metode ini sangat mudah dilakukan dengan biaya rendah karena menggunakan bahan kimia sederhana dan ramah lingkungan karena tidak menggunakan bahan kimia berbahaya.

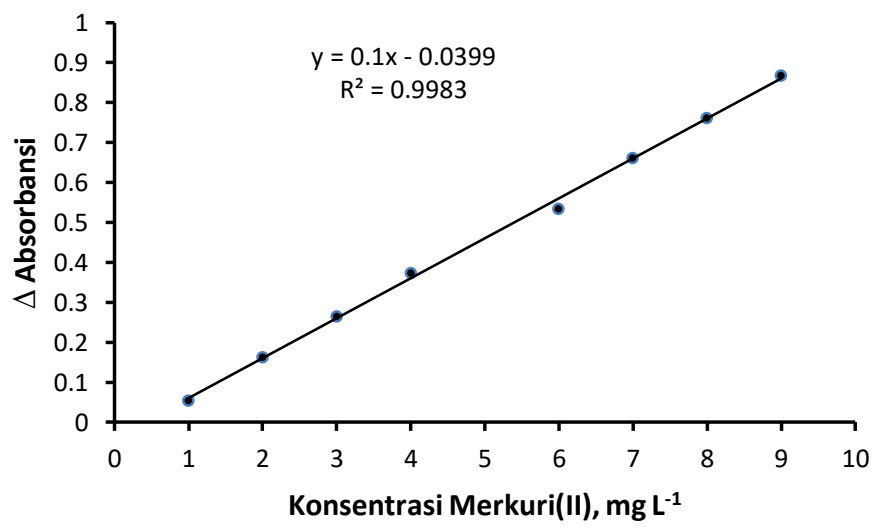

Gambar 5. Kurva linieritas pengukuran merkuri(II) (Kondisi: larutan 1-9 mg L $\mathrm{m}^{-1}$ merkuri(II); $3 \mathrm{~mL} 500 \mathrm{mg} \mathrm{L}^{-1}$ iodid; $6 \mathrm{~mL} 50 \mathrm{mg} \mathrm{L}^{-1}$, iodat, $0.05 \%$ larutan amilum, dan $\mathrm{pH} 1)$.

\section{Pengaruh ion asing}

Pengaruh ion asing terhadap pengukuran diperlukan untuk uji selektivitas metode yang dikembangkan. Pengaruh ion asing yang dipelajari dalam metode ini meliputi ion-ion logam 
yang seringkali ditemukan berada bersama merkuri(II), yaitu $\mathrm{Cu}(\mathrm{II}), \mathrm{Co}(\mathrm{II}), \mathrm{Pb}$ (II) dan $\operatorname{Ag}(\mathrm{I}))$ dalam sampel limbah baik di air maupun pertambangan. Pemilihan ion asing juga didasarkan pada kemungkinan bahwa ion-ion yang dipilih tersebut berpotensi untuk membentuk ikatan kompleks atau mampu membentuk endapan dengan ion iodida. Sementara itu, ion merkuri(II) membentuk kompleks yang sangat stabil dengan iodida dengan nilai Log Kst tinggi, yaitu 30 (Jeffrey et al., 1998).

Pengaruh ion asing dipelajari sebagai selektivitas metode dan dilakukan dengan cara mempersiapkan beberapa tabung berisi larutan merkuri(II) $1 \mathrm{mg} \mathrm{L}^{-1}$ yang kemudian ditambahkan masing-masing ion asing dengan bervariasi konsentrasi yaitu 1, 5, dan 10 kali lebih besar dari konsentrasi merkuri(II). Gambar 6 merupakan hasil percobaan pengaruh ion asing terhadap absorbansi, dimana gangguan ion asing terhadap pengukuran konsentrasi ion merkuri(II) ditandai dengan adanya perubahan absorbansi terhadap larutan merkuri yang tidak mengandung ion asing.

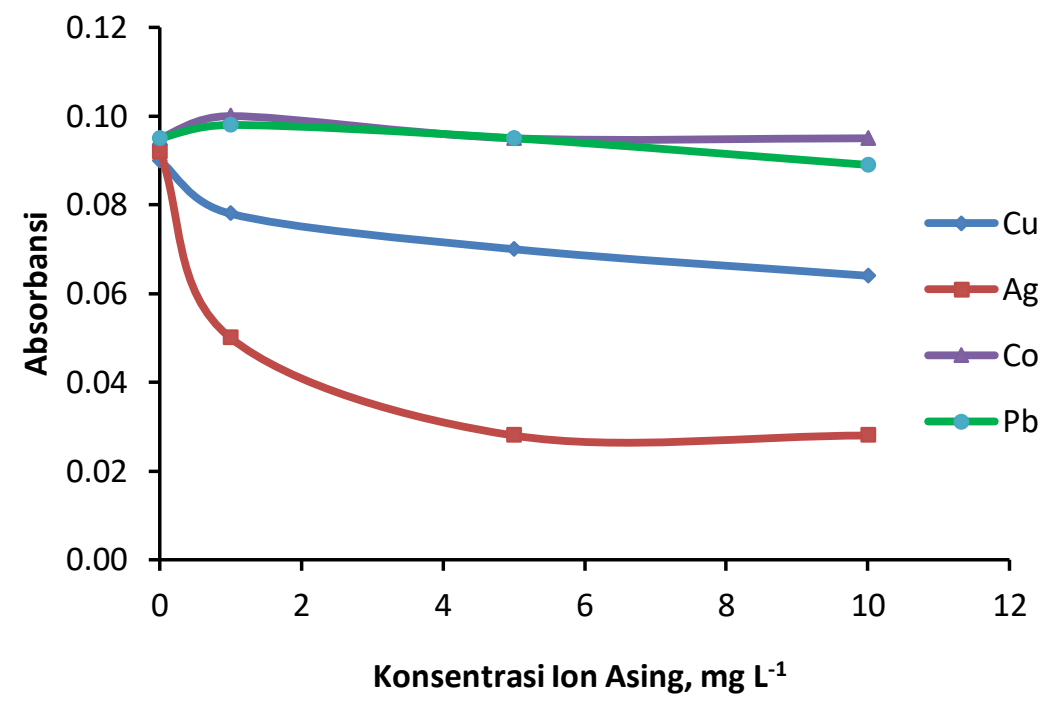

Gambar 6. Pengaruh ion asing terhadap absorbansi pengukuran (Kondisi: larutan $1 \mathrm{mg} \mathrm{L}^{-1}$ merkuri(II); ion asing $\left(0,1,5,10 \mathrm{mg} \mathrm{L}^{-1}\right), 15 \mathrm{mg} \mathrm{L}^{-1}$ iodida, $3 \mathrm{mg} \mathrm{L}^{-1}$ iodat, $0.05 \%$ larutan amilum, $\mathrm{pH}$ 1).

Berdasarkan Gambar 6 terlihat bahwa keberadaan ion Co(II) pada konsentrasi hingga 10 lebih besar dalam larutan merkuri(II) tidak mengganggu pengukuran merkuri(II), dengan menunjukkan absorbansi yang relatif konstan dan memberikan recovery pengukuran sebesar 98,25\%. Hal ini bisa dimaklumi karena ion kobalt(II) tidak membentuk endapan maupun kompleks dengan iodida. Keberadaan ion $\mathrm{Pb}(\mathrm{II})$ hingga 5 kali lebih besar dari konsentrasi merkuri(II) juga bisa dikatakan tidak mengganggu, karena perbedaan absorbansinya terhadap larutan merkuri(II) tanpa ion $\mathrm{Pb}$ (II) masih dalam rentang standar deviasi (SD) pengukuran, dan sedikit mengganggu $(<7 \%)$ pada konsentrasi 10 kali lebih besar konsentrasi 
ion merkuri(II). Keberadaan ion $\mathrm{Pb}$ (II) relatif tidak mengganggu pengukuran dan

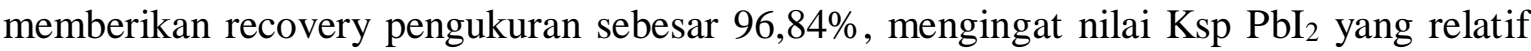
besar $\left(10^{-9}\right)$ sehingga pada konsentrasi kecil iodida tidak cukup untuk melampaui harga Kspnya. Keberadaan ion tembaga (II) atau $\mathrm{Cu}(\mathrm{II})$, dan ion perak(I) atau $\mathrm{Ag}(\mathrm{I})$, sudah mulai menggangu pengukuran pada konsentrasi yang sama dengan merkuri(II). Gangguan dari ion $\mathrm{Cu}$ (II) dikarenakan kemampuannya mengoksidasi iodida menjadi iodium atau direduksi oleh iodida menjadi ion $\mathrm{Cu}(\mathrm{I})$ yang mampu mengendap dengan ion iodida sesuai Reaksi 9 (Kaiho, 2014) membentuk endapan putih CuI dengan Ksp 1,27.10-12 yang lebih kecil dibandingkan $\mathrm{Ksp} \mathrm{PbI}_{2}$. Gangguan dari ion $\mathrm{Cu}(\mathrm{II})$ meningkat dengan meningkatnya konsentrasi ion $\mathrm{Cu}(\mathrm{II})$ terlihat dari penurunan absorbansi dari penambahan 1 - 10 kali lebih besar dari konsntrasi ion merkuri(II). Hal tersebut juga ditunjukkan dengan perhitungan recovery pengukuran sebesar $78,56 \%$.

$$
4 \mathrm{I}^{-}+2 \mathrm{Cu}^{2+} \rightleftharpoons 2 \mathrm{CuI}_{(\mathrm{s})}+\mathrm{I}_{2}
$$

Gangguan ion perak(I) memunjukkan gangguan yang paling nyata terhadap pengukuran ion merkuri(II) dibandingkan dengan ion logam lain dalam penelitian ini. Hal ini tidak mengejutkan karena ion perak(I) mampu membentuk endapan AgI dengan ion iodida dengan nilai konstanta hasil kali kelarutan, Ksp, yang sangat kecil, yaitu 8,3 $\times 10^{-17}$. Terlihat pada Gambar 6 bahwa keberadaan ion perak(I) dengan konsentrasi yang sama dengan ion merkuri(II), yaitu $1 \mathrm{mg} \mathrm{L}^{-1}$, langsung menurunkan absorbansi secara drastis dan keberadaan ion perak(I) $5-10 \mathrm{mg} \mathrm{L}^{-1}$ terjadi penurunan absorbansi secara maksimal. Hal tersebut juga ditunjukkan dengan perhitungan recovery pengukuran sebesar 38,43\%. Oleh karena itu, bila dalam sampel terdapat ion $\mathrm{Ag}(\mathrm{I})$ dan ion $\mathrm{Cu}(\mathrm{II})$ diperlukan perlakuan awal untuk menetralisir efek gangguannya sebelum dilakukan analisis $\mathrm{Hg}(\mathrm{II})$.

\section{Validasi Metode}

Validasi dari metode yang dikembangkan dapat diketahui dengan cara mengaplikasikan kondisi optimum yang diperoleh untuk menentukan konsentrasi merkuri(II) dalam sampel limbah pertambangan emas, Lombok Barat, Indonesia. Uji validasi dilakukan dengan cara menghitung persen perolehan kembali (\% Recovery) dari larutan merkuri(II) yang ditambahkan pada sampel limbah emas yang mengandung ion merkuri(II) menggunakan adisi standar. Metode adisi standar dilakukan dengan pengukuran konsentrasi merkuri(II) yang ada dalam limbah emas tanpa penambahan ion merkuri(II). Kemudian perobaan diulang dengan menambahkan ion merkuri(II) dengan konsentrasi yang berbeda (1, 2, dan $3 \mathrm{mg} \mathrm{L}^{-1}$ ) secara terpisah ke dalam masing-masing sampel pertambangan 
emas, kemudian dilakukan pengukuran konsentrasi merkuri pada masing-masing sampel limbah menggunakan metode yang dikembangkan. Penentuan recovery dilakukan dengan cara membandingkan hasil pengukuran konsentrasi ion merkuri(II) sampel limbah tanpa penambahan ion merkuri(II) dengan hasil pengukuran konsentrasi ion merkuri(II) sampel limbah yang ditambah dengan $\mathrm{Hg}$ (II) 1,2 dan $3 \mathrm{mg} \mathrm{L}^{-1}$. Hasil pengukuran metode adisi standard an perhitungan perolehan kembali ion merkuri(II) yang ditambahkan ditunjukkan pada Tabel 1 yang mengindikasikan bahwa metode analisis $\mathrm{Hg}$ (II) yang dikembangkan memberikan perolehan kembali yang memuaskan, dimana hasil pengukuran konsentrasi $\mathrm{Hg}$ (II) sesuai dengan konsentrasi yang ditambahkan dengan recovery rata-rata dan standar deviasi (SD) yang bisa diterima dalam analisis kuantitatif, yaitu $(99,59 \pm 0,68) \%$. Sesuai dengan (Harmita, 2004), Nilai recovery yang didapatkan masih dapat diterima karena rentang recovery yang diperbolehkan untuk pengukuran sampel dengan konsentrasi part per million (ppm) adalah 95 - $105 \%$. Metode ini mempunyai akurasi dan presisi yang baik sehingga berpotensi sebagai metode alternatif untuk analisis $\mathrm{Hg}(\mathrm{II})$ dalam sampel limbah.

Tabel 1. Penentuan merkuri(II) dalam sampel limbah pertambangan emas.

\begin{tabular}{|c|c|c|c|c|}
\hline No & Sampel & $\begin{array}{c}\text { Penambahan Hg(II) } \\
\left(\mathrm{mg} \mathrm{L}^{-1}\right)\end{array}$ & $\begin{array}{l}\text { Hg(II) terdeteksi" } \\
\left(\mathrm{mg} \mathrm{L}^{-1}\right)\end{array}$ & Recovery $(\%)^{*}$ \\
\hline 1. & Sampel limbah emas & 0 & $2,811 \pm 0,102$ & - \\
\hline 2. & Sampel limbah emas & 1 & $3,879 \pm 0,005$ & $105,82 \pm 0,526$ \\
\hline 3. & Sampel limbah emas & 2 & $4,753 \pm 0,023$ & $97,125 \pm 1,146$ \\
\hline 4. & Sampel limbah emas & 3 & $5,656 \pm 0,011$ & $95,838 \pm 0,383$ \\
\hline
\end{tabular}

\section{KESIMPULAN}

Metode spektrofotometri yang dikembangkan menunjukkan kinerja metode analisis yang cukup akurat dengan presisi yang baik dengan cara yang mudah, biaya operasional rendah, dan ramah lingkungan untuk analisis $\mathrm{Hg}(\mathrm{II})$ dalam kisaran $1-9 \mathrm{mg} \mathrm{L}^{-1}$. Metode ini berpotensi untuk diterapkan dalam analisis sampel $\mathrm{Hg}$ (II) limbah pertambangan. Metode ini cukup selektif terhadap ion $\mathrm{Co}$ (II) dan $\mathrm{Pb}$ (II). Jika terdapat ion $\mathrm{Cu}$ (II) dan $\mathrm{Ag}$ (I), diperlukan perlakuan pengompleksan terlebih dahulu dalam preparasi sampel sebelum analisis $\mathrm{Hg}$ (II) untuk mencegah gangguan pengukuran.

\section{UCAPAN TERIMAKASIH}

Penulis mengucapkan terimakasih kepada Kemenristek-Dikti atas pembiayaan penelitian melalui hibah PUPT (Penelitian Unggulan Perguruan Tinggi) dan Universitas Brawijaya atas fasilitas laboratorium untuk melakukan penelitian. 


\section{DAFTAR PUSTAKA}

Burgot, J.L., 2012. Ionic Equilibria in Analytical Chemistry, Springer Science, London, 442.

Hageman, P.L., 2007. Determination of Mercury in Aqueous and Geologic Materials by Continuous Flow-Cold Vapor-Atomic Fluorescence Spectrometry (CVAFS), US Geological Survey, Reston, Virginia, Book V, Chapter 2 D.

Hamza, A., Bashammakh, A.S., Al-Sibaaia, A.A., Al-Saidi, H.M., El-Shahawi, M.S., 2010. Part 1. Spectrophotometric Determination of Trace Mercury (II) In Dental-Unit Wastewater and Fertilizer Samples Using The Novel Reagent 6-Hydroxy-3-(2Oxoindolin-3-Ylideneamino)-2-Thioxo-2H-1,3-Thiazin-4(3H)-One And The DualWavelength B-Correction Spectrophotometry, Journal of Hazardous Materials. 1789(1-3) 287-292.

Harmita., 2004. Petunjuk Pelaksanaan Validasi Metode dan Cara Perhitungannya, Majalah Ilmu Kefarmasian. Vol 1. No 3.

Jeffrey, G.H., Basset, J., 1998. Mendham J., Denney, R.C., Vogel's Textbook of Quantitatif Chemical Analysis, $6^{\text {th }}$ ed., Longman Scientific \& Techncal, England.

Kaiho, T., 2014. Iodine Chemistry and Application, John Willey \& Sons, New Jersey, 376.

Leal, L.O., Elsholz, O., Forteza, R., Cerda, V., 2006. Determination of Mercury by Multisyringe Flow Injection System with Cold-Vapor Atomic Absorption Spectrometry, Analytic Chemistry, Vol. 573-574, 399-405.

Loo, A.Y.W., Lay, Y.P., Kutty, M.G., Timpe. O., Behrens, M., Hamid, S.B.A., 2012. Spectrophotometric Determination of Mercury with Iodide and Rhodamine B, Sains Malaysia, 41(2). 213-218.

Muralidhara, B.. 1998. Indirect Complexometric Determination of Mercury Using Potassium Iodide as Selective Masking Agent, Turky Journal Chemistry. 22. 215219.

Reddy, G.C., 2011. Derivative Spectrophotometric Determination of Mercury (II) Using Diacetyl Monoxime Isonicotinoyl Hydrazone (DMIH), International Journal of Chemistry, 3(2). 227.

Renneberg, A.J., Dudas, M.J., 2001. Transformations of Elemental Mercury To Inorganic And Organic Forms In Mercury And Hydrocarbon Co-Contaminated Soils, Chemosphere, 45, 1103-1109.

Grenberg, A.E., Clesceri, L.S., Eaton, A.D., Standard Method for the Examination of Water and Wastewater, American Public Health Association (APHA)., 1992. 17th ed., Washington, D.C.

Sulistyarti, H., Atikah, S., Fardiyah, Q., Febriyanti, S., Asdauna. A., 2015. Simple and Safe Spectrophotometric Method for Iodide Determination, Makara Journal of Science, 19(2), 43-48.

Svehla, G., 1979. Vogel's Textbook of Macro and Semimicro Qualitative Inorganic Analysis $5^{\text {th }}$ ed., Longman Group., London. 
US-EPA., 1997. Mercury Study Report to Congress, Volume III, Fate and Transport of Mercury in the Environment.

Veerana, V., Prasad, A.R.G., Rao, V.S., 2011. A Novel Spectrophotometric Method For The Micro Determination Of Mercury (II), Analele Universităţii din Bucuresti-Chimie, 20(1). 57-64.

WHO, 2003. Concise International Chemical Assessment Document 50 Elemental Mercury and Inorganic Mercury Compounds: Human Health Aspects, Geneva. 